CAHIER DE RECHERCHE \#1708E

Département de science économique

Faculté des sciences sociales

Université d'Ottawa
WORKING PAPER \#1708E

Department of Economics

Faculty of Social Sciences

University of Ottawa

\title{
Has Uber Made It Easier to Get a Ride in the Rain?*
}

\author{
Abel Brodeur ${ }^{\dagger}$ and Kerry Nield ${ }^{\ddagger}$
}

May 2017

\footnotetext{
${ }^{*}$ We are grateful to Cristina Blanco-Perez, Pierre Brochu, Jason Garred, Anthony Heyes, Kim Huynh, LouisPhilippe Morin, Matt Webb and seminar participants at the Bank of Canada and SCSE for very useful remarks and encouragement. We thank Mitch Prior for outstanding research assistance. The paper was written while Kerry Nield was completing graduate studies at Carleton University. The views expressed in this paper are those of the authors. No responsibility for them should be attributed to the Bank of Canada. All errors are our own.

${ }^{\dagger}$ Corresponding author. Department of Economics, University of Ottawa, 120 University Private, Ottawa, Ontario, Canada, K1N 6N5; e-mail; abrodeur@uottawa.ca.

* Currency Department, Bank of Canada, 234 Wellington Street, Ottawa, Ontario K1A 0G9, Canada. Phone: +1 (613) 782 8907. E-mail: knield@bankofcanada.ca.
} 


\begin{abstract}
In New York City (NYC), it has been a common complaint that it is difficult to find a taxi in the rain. Using all Uber rides in NYC from April to September 2014 and January 2015 to December 2016, we show that the number of Uber rides is significantly correlated with whether it rained. The number of Uber rides per hour is about 18 percent higher when it is raining, suggesting that surge pricing encourages an increase in supply. During the same time period, the number of taxi rides per hour increases by only 5 percent in rainy hours. We then show that the number of taxi rides, passengers and fare income all significantly decreased after Uber entered the New York market in May 2011, suggesting that Uber is depressing taxi demand. Last, we test whether the total (Uber plus taxi) number of rides in rainy hours increased since May 2011. Our estimates suggest that it is relatively easier to get a ride in rainy than in non-rainy hours in post-Uber years.
\end{abstract}

Key words: Rain, Uber, Taxi, Dynamic Pricing.

JEL Classification: D01, D03, L92, J22. 


\section{Introduction}

Standing or walking in the rain is an activity best avoided. In New York City (NYC), when faced with such inclement weather, the demand for personal transportation naturally increases. During such scenarios, taxi drivers spend less time searching for customers and could thus earn a higher wage. Nonetheless, it has been a common complaint that it is difficult to find a taxi in the rain.

One plausible explanation for the difficulty of finding a taxi in the rain is that taxi drivers have a daily income target and stop working once they reached this target 1 On rainy days taxi drivers reach their target faster and work less hours. ${ }^{2}$ This view, however, has been called into question by Farber (2015). In this recent study, he rejects the idea that target earnings behavior explains the difficulty to find taxis when it rains. Instead, Farber (2015) provides evidence that some drivers stop working because of the worsening driving conditions associated with rain; unfavorable working conditions for which there is no compensating differential.

As an alternative service to taxis, Uber entered the NYC market in May 2011 with surge pricing and mobile driver-passenger matching technology. Surge pricing is a pricing scheme implemented by Uber where passengers pay a higher rate for the Uber service during times of high demand; this higher pricing scheme gives incentives to Uber drivers to provide rides in inclement conditions. Uber could thus be a logical response to unmet demand during adverse conditions.

Previous studies on intertemporal substitution of labor supply find mixed evidence of temporal substitution effects. (See Blundell and MaCurdy (1999) for a review of the literature.) Fehr and Goette (2007) conduct a field experiment at a bicycle messenger service in Switzerland in which they vary temporarily the piece rate paid to messengers. They find a large positive elasticity of hours of work, but a negative elasticity of effort per hour. In another experiment, Chang and Gross (2014) document that pear packers in California respond to unexpected overtime by decreasing their

\footnotetext{
${ }^{1}$ See Koszegi and Rabin (2006) for a model of reference-dependent preferences and loss aversion. They build on the work of Kahneman and Tversky (1979) and Tversky and Kahneman (1991) and develop a model where a person's utility depends on a reference point.

${ }^{2}$ In a seminal article, Camerer et al. (1997) present evidence suggesting that taxi drivers have income reference-dependent preferences, so that taxi drivers have a daily income target and stop working once they reached this target. Note that Camerer et al. (1997) were not particularly interested in rain and did not claim that on rainy days taxi drivers reach their target faster and work less hours. We thank Colin Camerer for pointing this out.
} 
effort. In Oettinger (1999), the author studies labor supply of stadium vendors at baseball games and finds that the number of vendors who worked in a game is positively related to changes in expected wages. In contrast to earlier studies, we have the unique opportunity of comparing two groups of workers, Uber and taxis in NYC, who are facing different unanticipated wage increases in response to exogenous circumstances. Another key feature of our analysis is that we can test whether the taxi market changed since Uber entered the on-demand transportation network in NYC.

This paper makes four contributions. First, we provide an empirical examination of whether the number of Uber rides increases more than the number of taxi rides when it rains. For this analysis, we rely on all Uber and taxi rides in NYC from April-September 2014 and January 2015 to December 2016 and merge the Uber and taxi data with weather data from the National Weather Service Observatory in Central Park. The results suggest that the number of Uber rides per hour is significantly correlated with whether it rained. More precisely, the number of Uber rides per hour is about 18 percent higher when it is raining, suggesting that surge pricing encourages an increase in supply $!^{3}$ This increase in transactions when it rains likely reflects a large increase in both demand and supply. On the other hand, the number of taxi rides per hour increases by only 5 percent in rainy hours during this time period.

Second, we test whether rain increases the number of daily rides. We provide evidence that the number of Uber rides increases by approximately 8 percent during rainy days and that an additional hour of rain increases the number of Uber rides per day by approximately 2 percent. On the other hand, there is weak evidence that the daily number of taxi rides is related to rain. The number of taxi rides increases by approximately 2 percent during rainy days. This is suggestive evidence that Uber drivers do not have a daily target income level and that Uber driver labor supply is best characterized by the neoclassical model.

Third, we use data for all trips taken in NYC taxi cabs before (January 2010-April 2011) and after (2014-2016) Uber's rise in popularity, and show that the number of taxi rides per hour decreased by approximately 27 percent after Uber entered the New York market in May 2011. The results indicate that the number of taxi rides in both rainy and non-rainy hours have similarly decreased since Uber entered the market. Moreover, we show that hourly fare income and the number of passengers per hour for taxis

\footnotetext{
${ }^{3}$ Unfortunately, our data set does not allow us to test whether the increase in labor supply of Uber drivers during rainy hours is due to the extensive or intensive margin.
} 
significantly decreased after Uber entered the market, suggesting that Uber is depressing taxi demand.

Finally, we document whether it is easier to find a ride since Uber entered the market. For this exercise, we combine Uber and taxi rides for 2014-2016 and compare the total number of rides post-Uber to the number of taxi rides during the pre-Uber period (January 2010-April 2011). We find that the total number of rides remained stable since May 2011, but that it was relatively easier to get a ride in rainy than in non-rainy hours in 2014-2016.

This paper contributes to the literature analyzing labor supply of taxi drivers Agarwal et al. (2015), Buchholz (2016), Camerer et al. (1997), Chou (2002), Crawford and Meng (2011), Doran (2014), Farber (2008), Haggag and Paci (2014) and Haggag et al. (2017)). Two relevant papers using NYC data are Farber (2005) and Ashenfelter et al. (2010). Farber (2005) studies the stopping behavior of NYC taxi drivers and finds that the decision to stop working is primarily related to cumulative daily hours. Ashenfelter et al. (2010) also study the labor supply of taxi drivers. They analyze the impact of two permanent fare increases and find an elasticity of labor supply of -0.2 in response to these fare increases.

Our work also contributes to a small economic literature on the Uber platform. Despite its media attention, few research papers analyze the impact of Uber on the labor supply of taxi drivers. The dearth of research on this issue is mainly driven by the lack of publicly available data. In this paper, we rely on Uber data in NYC that were recently made publicly available. Two recent papers using different Uber data are Chen and Sheldon (2015) and Cramer and Krueger (2016). In Chen and Sheldon (2015), the authors use a randomly drawn subset of UberX driver-partners in a few American cities. 4 They find that UberX partners are less likely to quit at times with high surge prices. Cramer and Krueger (2016) compare capacity utilization for taxis and UberX drivers in five American cities. They provide evidence that the capacity utilization rates of taxi and UberX drivers are very similar in NYC 5 They point out that this may be due to the high

\footnotetext{
${ }^{4}$ UberX cars can carry up to four riders and have four doors. The full list of Uber vehicle classes is available here: http ://driveubernyc.com/vehicles/full-list.

5 Hall and Krueger (2016) compare Uber's driver-partners labor market demographic to taxi drivers. They find that Uber's driver-partners are more similar to the general workforce than taxi drivers and chauffeurs. In particular, Uber drivers are comparatively more educated and younger. Cohen et al. (2016) estimate consumer surplus for UberX in four U.S. cities. They rely on Uber's surge pricing algorithm to estimate demand elasticities and find that demand is quite inelastic (i.e., price elasticities between -0.4 and -0.6$)$.
} 
population density which supports more efficient matching of taxis.

The paper is structured as follows. In the following section, we provide a description of Uber and surge pricing. In Section 3, we detail the data sets and provide descriptive statistics. Section 4 presents the model specification. Section 5 discusses our findings of the impact of rain on Uber and taxi rides. The last section concludes.

\section{Conceptual Framework}

This section provides insights on how rain might impact the number of Uber and taxi rides in theory. We consider two alternative mechanisms. The first builds on standard neoclassical intertemporal models of labor supply (e.g., Fehr and Goette (2007); Oettinger (1999)) and treats surge pricing as a transitory wage change for Uber drivers. The second is based on models of reference-dependent preferences in which drivers stop working once they reach their target income level (e.g., Camerer et al. (1997); Koszegi and Rabin (2006)).

A key hypothesis in this study is that adverse weather conditions cause an increase in the demand for alternative on-demand sources of transport such as taxis or Uber cars. ${ }^{6}$ During rainfall, it is generally considered to be undesirable to be outside (Connolly (2008)). As such, individuals who would generally walk or wait for public transit may wish to utilize taxis or Uber cars. Importantly, we assume that the increase in demand for rides during rainy hours is similar in pre- and post-Uber years.

\subsection{Intertemporal Models of Labor}

A simple neoclassical intertemporal model of labor predicts that workers respond positively to earnings opportunities. This model implies that unanticipated increases in earnings opportunities such as rain would positively affect labor supply elasticities. In other words, this model predicts that drivers would be working more on high-wage days and less on low-wage days.

A rational choice model with reference-dependent preferences suggests that workers who temporarily earn higher wages will eventually decrease their effort. For instance, cab and Uber drivers who have a reference level of daily income would work more in rainy hours. As they get closer to their

\footnotetext{
${ }^{6}$ The New York subway provided significantly more rides than Uber and taxi drivers. Subway and bus ridership statistics are available here: http : //web.mta.info/nyct/facts/ridership/.
} 
daily reference level, the marginal utility of income would be decreasing which in turn would reduce their effort.

The neoclassical model and the model with reference-dependent preferences that exhibit loss aversion around a daily target income level both suggest that rain increases hourly rides. On the other hand, only the former predicts that rain increases daily rides. Using all trips taken in NYC taxis from 2009-2013, Farber (2015) tests whether rain affects earnings, utilization rates and the number of hacks on the streets. He finds that rain has no effect on hourly earnings, but does cause higher utilization of cabs, and in general shorter trips. This is indicative of increased demand for rides when it rains. However, there is also a decreased number of taxis on the streets which is, arguably, due to the disutility experienced by taxi drivers driving in uncomfortable weather conditions. Farber (2015) concludes that these results are "sufficient to reject the hypothesis that target earnings behavior contributes to the difficulty of finding a taxi in the rain [...]"

Unlike taxis, the Uber platform adjusts its prices using a realtime dynamic algorithm (Chen and Sheldon (2015)).7 The Uber fare rates automatically increase when demand is higher than supply of drivers within a fixed geographic area. Customers are informed of the higher fare before requesting the Uber car. Uber drivers are also aware of surge pricing and have access to maps displaying the locations currently surge pricing ${ }^{8}$ Uber drivers may freely choose when they work and they can drive as long as they like. This is thus an ideal setting for studying intertemporal models of labor (Fehr and Goette (2007)).

As there is no rain surcharge for taxis, taxi drivers may be less likely to respond to the increased demand for rides. Uber platforms could then benefit consumers if Uber drivers respond to the unmet demand when it rains. The extra compensation that Uber drivers receive through surge pricing may incentivize them to overcome the disutility of adverse conditions.

Factors other from surge pricing may explain why Uber drivers work more (or are more likely to work) when it rains. First, while driving is a primary occupation for most traditional cab drivers, it is a secondary job for many Uber drivers (Chen et al. (2017)). Arguably, hours supplied to a secondary job are more elastic than hours supplied to a primary job. Second, the restricted supply of taxi cabs available to drive in the rain may limit the behavioral response of (potential) taxi drivers. Another explana-

\footnotetext{
${ }^{7} \mathrm{~A}$ major difference between taxis and Uber is that Uber drivers do not need to purchase one of the city's prized taxi medallions. The cost of a taxi medallion is often hundreds of thousands of dollars.

${ }^{8}$ Surge multipliers are discrete and there is no cap in NYC.
} 
tion is that taxi and Uber drivers have a different aversion to driving in inclement weather. For instance, Hall and Krueger (2016) find that there is a greater representation of younger people among Uber drivers than among taxi drivers. The response to weather conditions could then be due to both surge pricing and drivers' aversion to risk.

\subsection{Evaluating the Effect of Rain}

We test four hypotheses in what follows. First, we test whether the number of Uber rides increases significantly more than the number of taxi rides in rainy hours. Due to surge pricing, among other reasons, we expect that the number of rides given by Uber drivers increases significantly more than the number of taxi rides in the rain. Such a result would provide some evidence that the wage increase caused an increase in Uber drivers' labor supply.

Second, we investigate whether rain increases the number of daily rides for both taxis and Uber. The neoclassical model predicts that rain increases significantly the number of daily rides. On the other hand, if drivers have a daily target income level, then we should find that rainy days are not significantly related to taxi and Uber rides. Note that it is possible that drivers have a weekly or monthly target income level. Unfortunately, the sample size is too small to estimate precisely whether this is the case.

Third, we test whether taxi drivers' supply response to rain changed since Uber entered the market. The lack of rain surcharge for taxis and the increasing presence of Uber drivers when it rains may increase the difficulty of finding customers for taxi drivers. We test this using taxi rides data preand post-Uber.

Last, we test whether the total (Uber plus taxi) number of rides increased or decreased since May 2011. We also test whether it was relatively easier to get a ride in rainy than in non-rainy hours in post-Uber years. Note that the presence of Uber does not automatically increase the total number of rides. As mentioned before, there might be a substitution of rides from taxi to Uber and the disutility of adverse conditions for taxi drivers might have changed since May 2011. It thus remains unclear whether the total number of rides in the rain increased proportionally more than the total number of rides in non-rainy hours since Uber entered the market. 


\section{Data Sources}

\subsection{Data on Uber and Taxi Rides}

This study relies on all trip level data of Uber pickups in NYC from April to September 2014 and January 2015 to December 2016. This data set was made available by the New York Taxi Commission (TLC). This data set includes approximately 110 million rides reported from the dispatching bases Uber utilizes in NYC. Uber cars are classified as for-hire vehicles by the TLC.

Individual trip level data for taxi rides are also available for this time frame. TLC has publicly released trip level data for all yellow taxi rides dating back to 2009. This is when the TLC started to require that digital trip records be kept through car GPS devices. For this time period, we calculated the number of rides that occurred hourly for both Uber and taxis. This was done using the time of the pick up. For taxis, we also compute the hourly number of passengers and the total time-and-distance fare as calculated by the taxi meter per hour. Note that taxi rides going to the airport are excluded for these two additional variables. The total time-anddistance fare does not include extra charges, such as the rush hour $(\$ .50)$ and overnight charges $(\$ 1)$, the $\$ .50$ MTA tax, or the $\$ .30$ improvement surcharge that started in 2015. It also does not include tip amount, or tolls amount. Unfortunately, we cannot compute these additional variables for Uber since we do not observe the price of each ride nor surge price.

Figure 1 shows the number of rides per quarter since 2009 for taxis and over the period April to September 2014 and January 2015 to December 2016 for Uber. Note that Uber entered the New York market in May 2011. What emerges is that the number of taxi rides is much larger than the number of Uber rides in 2014. During the second quarter of 2014, when Uber had been in the market for nearly three years, there were approximately 23 times more taxi rides than Uber rides. But this gap has decreased sharply. During the last quarter of 2016, the most recent quarter in our analysis, there were approximately 1.4 times more taxi rides than Uber rides. Figure 1 suggests that this decreasing gap is due both to an increase in Uber rides and a decrease in taxi rides.

Figure 2 displays the number of taxi passengers and total time-anddistance fare as calculated by the taxi meter per quarter for the period 2010-2016. The number of passengers per quarter for taxis decreased by approximately 16 million passengers from 2010 to 2016 while total time- 
and-distance fare per quarter decreased by approximately $\$ 30$ million in 2010 dollars 9

The differential in rides during rainy hours also decreased during this time period. During the second and third quarters of 2014, there were respectively 3.9 million taxi rides and 236,000 Uber rides during rainy hours (i.e., 16 times more taxi rides than Uber rides). During the second and third quarters of 2016, the gap was down to 1.2 million, with 1.4 million Uber rides and 2.6 million taxi rides (i.e., less than two times more taxi rides than Uber rides in rainy hours).

For our analysis, two subsets of the taxi data set are used. A first taxi data from April to September 2014 and January 2015 to December 2016 (2014-2016 henceforth) is used, as it is a direct comparison to the time frame for which Uber data are available. A second subset, from January 2010-April 2011 (2010-2011 henceforth), is used as well. We rely on this second subset which covers a period before Uber entered the NYC market as a comparison for taxi drivers' response in post-Uber market conditions.

We provide descriptive statistics for Uber and taxi rides per hour in Panel A of Table 1. (See Appendix Table A1 for Uber and taxi rides per day.) The average number of Uber rides per hour is 5,076 over the period 2014-2016. During the same time period, the average number of taxi rides per hour was 16,439. This is a small decrease in comparison to the average number of taxi rides over the period 2010-2011 $(19,519)$. The standard deviation of taxi rides has also decreased in this same time frame. Panels B and C provide the same summary statistics as in Panel A, but for two sub-samples: 1) excluding nighttime observations (1:00 to 5:00 AM), and 2) excluding winter months (January-March). The average number of rides per hour is higher when we exclude nighttime observations and the number of Uber and taxi rides is somewhat similar for winter and non-winter months 10

\subsection{Weather Data}

The above data sets are combined with weather data from the National Weather Service Observatory in Central Park. This data set was collected using scraping techniques from www.wunderground.com. The observatory

\footnotetext{
${ }^{9}$ We use the Consumer Price Index for All Urban Consumers (All items) in New York-Northern New Jersey-Long Island to deflate prices.

${ }^{10}$ Appendix Figures 3 and 4 confirm that the fraction of rides is lower for nighttime observations by showing the fraction of rides per hour of day for Uber and taxis (postUber). The fraction of Uber rides from 5:00 to 10:00 PM is slightly larger than the fraction of taxi rides while this is the opposite from 8:00 AM to 1:00 PM.
} 
reports observations at 51 minutes past the hour. As such, when the number of rides per hour were calculated, the number of taxi trips occurring in the half hour preceding and following the weather observation was aggregated into a single observation. For example, for a 10:51 AM weather observation, the number of rides occurring from 10:21:00 AM to 11:20:59 AM would be counted. Each observation reports the weather condition of the time period. Possible conditions include "Clear", "Heavy Rain", "Rain", "Light Rain" or "Partly Cloudy". A full list of weather conditions can be seen in Table 2 ,

Comparing the number of different weather condition observations from 2010-2011 to 2014-2016, we find that there is a somewhat similar proportion of instances of each condition. There was "Rain" or "Light Rain" in 4 percent of the observation in 2014-2016 in comparison to 4.2 percent in 2010-2011. The condition is coded as "Heavy Rain" in 0.3 percent of the observation in both time periods. It was "Clear" for 53 percent of the observations in both time periods ${ }^{11}$

\section{Identification Strategy}

In this section, we describe the main specification and the controls. The objective is to investigate the impact of rain on Uber and taxi rides. To identify this effect, we use trip level data to calculate the number of rides for each of the clock hours in the time period analyzed. Our unit of observation is an hour. As mentioned before, the time period is April-September 2014 and January 2015 to December 2016 for the Uber analysis. We then compare this time period to a pre-Uber time period: January 2010-April 2011.

In our main specification, we estimate:

$$
Y_{h m y}=\alpha+\beta R A I N_{h m y}+\delta_{m}+\gamma_{y}+X_{h m y}^{\prime} \lambda+\varepsilon_{h m y}
$$

where $Y_{h m y}$ is the log of the number of Uber rides (or taxi rides) in hour $h$, month $m$ and year $y$. RAIN $N_{h m y}$ is a dummy that equals one if it rained in Central Park in hour $h$ and zero otherwise. More precisely, $R A I N_{h m y}$ is equal to one if the conditions were noted as "Heavy Rain", "Rain", "Light Freezing Rain" or "Light Rain". We include month and year fixed effects

\footnotetext{
${ }^{11}$ There are also some cases where the observatory does not report the conditions at the 51st minute. The number of observations where this is the case is 28 in 2014-2015. The observatory also has 51 cases of instances where the reported weather condition was "unknown" in 2014-2015. These observations are removed from the analysis.
} 
and $X_{h m y}$ is a vector of other regressors that includes indicators for hour of day by day of week, snow and major holiday 12 The coefficient of interest here is $\beta$.

We check the robustness of our results by removing outliers. First, we check that the association of rain and the number of rides per hour is robust to using a subset of the data set that removes the winter months. The winter months are identified in this research as January, February and March. Second, we exclude nighttime observations since the number of rides is lower during that time of the day. Last, we test the robustness of our findings by excluding from the analysis the more severe weather events "Heavy Rain" and "Light Freezing Rain".

Our econometric model for testing the effect of Uber's rise in popularity on the number of taxi rides in rainy hours is as follows:

$$
\begin{aligned}
Y_{h m y}= & \alpha+\beta R A I N_{h m y}+\text { PPostUber }_{h m y} \\
& +\sigma R A I N_{h m y} \times \text { PostUber }_{h m y}+\delta_{m}+X_{h m y}^{\prime} \lambda+Z_{m y}^{\prime} \mu+\varepsilon_{h m y},
\end{aligned}
$$

where the dependent variable is the log of the number of taxi rides in an hour $h$, month $m$ and year $y$. PostUber is a variable that takes the value 1 if the year is after 2011. The interaction of RAIN and PostUber shows the effect of the introduction of Uber's platform in $\mathrm{NYC}$ on taxi rides in rainy hours. We include month fixed effects, our vector of time dummies $\left(X_{h m y}\right)$ and control for demand-side factors such as the natural log of population (18 years and over) at the year level and the monthly unemployment rate $\left(Z_{m y}\right)$.

The interpretation relies on the identification condition that there are no other time-varying shocks that affect the number of taxi rides. Our analysis of taxi drivers' labor supply pre- and post-Uber should thus be viewed with caution since there were at least two changes in the New York taxi market during the time frame of investigation. First, Green taxi cabs (i.e., Boro taxis), which are able to serve the boroughs of New York and drop passengers off in the Manhattan core, began operating in 2013. Note that these cabs are unable to pick up trips in the south of Manhattan. We thus exclude Green taxi cabs from the analysis. Note that the introduction of Green taxi cabs may also encourage taxi drivers to compete more vigorously. Second, from September 4, 2012 through December 31, 2013 a

\footnotetext{
${ }^{12}$ The dummy for snow is equal to one if the conditions were noted as "Snow", "Heavy Snow" or "Light Snow" and zero otherwise. Major holidays include New Years Day, Martin Luther King Day, Lincoln's Birthday, President's Day, Memorial Day, Independence Day, Labor Day, Columbus Day, Veterans Day, Thanksgiving and Christmas Day.
} 
higher rate for fifth of a mile was enacted (Farber $(2015))$.

\section{Results}

\subsection{Impact of Rain on Hourly Rides Post-Uber}

We first estimate the effect of rain on taxi rides per hour. While our time period and dependent variables are different than in Farber (2015) (20092013), his results provide a useful benchmark. Farber (2015) finds that there are approximately 7.1 percent less cabs in NYC when it is raining, but that taxi utilization rates (i.e., time with passengers) in the rain are 4.8 percent higher, and trips take 2.4 percent less time. We then test whether the effect of rain is similar for the number of Uber rides. If the demand is unmet in rainy hours, then Uber's surge pricing could encourage an increase in supply.

Table 3 contains OLS estimates of equation (1) for Uber and taxi rides over the April-September 2014 and January 2015 to December 2016 periods (i.e., post-Uber period). The sample size is 21,423 observations (i.e., hours). The dependent variables are, respectively, the log of the number of taxi rides per hour in columns 1-3 and the log of the number of Uber rides per hour in columns 4-6. We report standard errors clustered by hour of day by day of week (168 clusters) in parentheses. What clearly emerges is that rainy hours are associated with a small increase in taxi rides and a large increase in Uber rides. In columns 1 and 4, we do not include any fixed effects and find that Uber rides increase by approximately 14 percent while taxi rides increase by only 1 percent. We include our set of time fixed effects in columns 2 and 5. The number of Uber rides is about 19 percent higher when it is raining and the estimate is significant at the 1 percent level. On the other hand, the number of taxi rides per hour increases by only 5 percent. In columns 3 and 6 , we test the robustness of our estimates by excluding nighttime observations. The estimates are slightly larger for Uber rides, but the difference is not statistically significantly different from the estimates including nighttime observations.

Table 4 provides additional robustness checks. The structure of the table is similar to Table 3 . We exclude respectively hours of heavy rain and light freezing rain in columns 1 and 4 and the months of January, February and March in columns 2 and 5. These specification checks confirm that Uber rides increase by approximately 18 percent in rainy hours while taxi rides increase by only 5 percent. 
In columns 3 and 6 , we separately test the effect of light rain and heavy rain on rides per hour. The variable Light Rain is equal to one if the condition is "Light Rain" and zero otherwise, while the variable Rain \& Heavy Rain is equal to one if the condition is either "Heavy Rain" or "Rain" and zero otherwise 13 The estimates are positive and significant for both variables when the dependent variable is the log of the number of Uber rides. The estimated coefficient is larger for Rain \& Heavy Rain (coeff. 0.299, std. error 0.022) than for Light Rain (coeff. 0.157, std. error 0.011) possibly suggesting that light rain does not increase demand as much as heavy rain. The estimates are also positive for taxi rides for both variables.

So far, our results are indicative that surge pricing encourages an overall increase in supply for Uber drivers. Unfortunately, it is impossible to test whether the increase in Uber rides during rainy hours is due to an increase in hours worked (intensive margin) or an increase in the number of Uber drivers working (extensive margin). Our results for the relationship between rain and taxi rides are consistent with the results of Farber (2015).

\subsection{Impact of Rain on Daily Rides Post-Uber}

In Table 5, we turn to presenting OLS estimates of the relationship between rain and daily rides. (See Appendix Table A2 for the other four taxi outcomes at the day level.) The time period is the same as in Table 3 and the dependent variables are, respectively, the log of the number of taxi rides per day in columns 1-3 and the log of the number of Uber rides per day in columns 4-6. Our variable of interest in columns 1, 2, 4 and 5, Rain Day, is a dummy that is equal to one if the conditions were noted as "Heavy Rain", "Rain", "Light Freezing Rain" or "Light Rain" at any point during the day and zero otherwise. In columns 3 and 6, we replace Rain Day with the variable Hours of Rain. Hours of Rain is a continuous variable that is equal to the number of hours of rain per day. Note that the average number of hours of rain in a rainy day is 3.94 (std. deviation 3.40). We include week, month and year fixed effects and holiday dummies in columns 2, 3, 5 and 6 .

The results suggest that the number of Uber rides increases by approximately 8 percent during rainy days. The estimate is significant at the 5 percent level. We also find that an additional hour of rain increases the number of Uber rides per day by 2 percent. The result that rain increases daily rides

\footnotetext{
${ }^{13}$ Note that coding the variable Rain \& Heavy Rain equals to one if the condition is "Light Freezing Rain" leads to similar estimates.
} 
provides evidence that Uber drivers do not have reference-dependent preferences in which workers have a reference level of daily income. Additional information on utilization rates and length of trips is required to confirm this result. There is also weak evidence that rain increases the number of taxi rides per day. The estimates are small, positive and statistically significant at the 10 percent level.

\subsection{Impact of Uber on Taxi Rides and Income}

In this subsection, we investigate whether the number of taxi rides, passengers and hourly fare income decreased after Uber entered the market. We also test whether the estimated effects of rain on these outcomes are similar in the pre-Uber era.

In Table 6, we test explicitly whether the number of taxi rides per hour reacts more to rain in the pre-Uber period than in 2014-2016. (See Appendix Table A3 for the analysis at the day level.) All columns include our time fixed effects. Column 1 first shows the relationship between the number of taxi rides and the variable PostUber. Column 1 shows that the number of taxi rides per hour decreased by approximately 27 percent in the post-Uber period. This result suggests that the market entry of Uber led to a significant decrease in taxi rides.

Column 2 adds our dummy variable for rain, but without the interaction with PostUber. Over the full period of study, the number of taxi rides in rainy hours increases by roughly 5 percent. Column 3 presents estimates of equation (2) where we include PostUber, the dummy for rain and the interaction term 14 The interaction term, $\sigma$, is positive, but not statistically significant at the 10 percent level. This means that the number of taxi rides in rainy hours has not decreased by more than in non-rainy hours since Uber entered the market. In column 4, we check the robustness of this result by interacting our month fixed effects $\left(\delta_{m}\right)$ with the indicator PostUber. The interaction term is negative and statistically insignificant.

Table 7 shows the effect of Uber on the other two taxi outcomes. The dependent variables are respectively the natural log of the number of taxi

\footnotetext{
${ }^{14}$ The interaction of RAIN and PostUber shows the additional effect of Uber entering the market on the variation of taxi rides in rainy hours. A negative estimate could suggest that there is a substitution of taxi rides to Uber rides, and especially so when it rains. A negative effect could also be indicative that that the disutility of driving in the rain for taxi drivers has increased since May 2011. If the increasing number of Uber drivers in rainy hours results in more competition to find passengers, this may decrease the time spent with a passenger and decrease the willingness to work in the rain for taxi drivers.
} 
passengers (Panel A) and the natural log of the total time-and-distance fare (in 2010 dollars) as calculated by the taxi meter per hour (Panel B). Column 1 presents the relationship between these outcomes and the variable PostUber. The estimates suggest that the number of taxi passengers decreased by approximately 19 percent in the post-Uber period. The association between total time-and-distance fare and the variable PostUber is significant at the 1 percent level and suggest that hourly fare income decreased by about 7 percent since May 2011.

Of note, though, our research focuses on a time period in which Uber was still growing. The analysis pre- and post-Uber could yield very different conclusions when Uber reaches its steady state. For instance, the negative impact on hourly fare income is much bigger if we exclude the year 2014 (coeff. -0.273, std. error 0.024). This is consistent with Figure 2 and with the idea that Uber was growing exponentially during the period 2014-2016.

We also present the estimated effects for the interaction term $\sigma$ in Table 7, column 3. Our estimates are statistically insignificant for the two outcomes in column 4 suggesting that the number of passengers and total time-and-distance fare in rainy hours have not decreased by more than in non-rainy hours since Uber entered the market.

\subsection{Impact of Uber on Total (Uber and Taxi) Rides}

Turning now to a different dependent variable, Table 8 shows the effect of Uber entering NYC's market on the total number of rides (i.e. Uber plus taxi rides) per hour. (See Appendix Table A4 for the analysis at the day level.) The layout is the same as in Table 6. The coefficients on the PostUber variable indicate that the total number of rides per hour (and per day) remained unchanged in the time period 2014-2016. As shown before, this result is due to the large increase in Uber rides and the large decrease in taxi rides.

The coefficient estimates for the rain dummy indicate that over the full period of study total rides increases by approximately 7.1 percent when it rains. Then, the next row shows the coefficient estimates for the interaction of the variables $R A I N$ and PostUber. The estimated coefficient is positive and statistically significant at the 1 percent level, suggesting that, since Uber entered the market, it is relatively easier to get a ride in rainy than in non-rainy hours. More precisely, we find that the number of total rides in rainy hours increased by 3.8 percent in post-Uber years.

In column 4 , we check whether this result is robust by interacting our 
month dummies and the indicator PostUber. The coefficient of interest remains positive and significant, suggesting that the result presented in column 3 is robust. In column 5 , we test whether the effect is significant for interaction of the variables Light Rain and PostUber and Rain \& Heavy Rain and PostUber. The estimates are both positive and statistically significant.

Our findings suggest that Uber has made it easier to get a ride in the rain. The results are consistent with a substitution from taxi rides to Uber rides and suggest that surge pricing encourages an increase in supply for Uber drivers.

\section{Conclusion}

Using all Uber rides in NYC from April-September 2014 and January 2015 to December 2016, we investigated the effect of rain on the labor supply of Uber drivers and found that the number of Uber rides per hour increases by approximately 18 percent when it is raining. During the same time period, the number of taxi rides per hour increases significantly less than the number of Uber rides in rainy hours. We also provided evidence that during rainy days, the number of rides increases by about 8 percent for Uber. On the other hand, the number of taxi rides per day is only weakly related to rain. That rain would have a different effect on taxi and Uber rides is in line with a neoclassical intertemporal model of labor, given that only Uber rides are subject to rain surge pricing.

Looking at the impact of Uber on taxis, we found that the number of taxi rides per hour decreased by 27 percent after Uber entered the New York market in May 2011. There was also a significant decrease in hourly fare income and the number of passengers per hour. These results are consistent with a substitution from taxis to Uber cars.

We then checked whether it was easier to find a ride in the rain after the entry of Uber in May 2011. We first compared the total (Uber plus taxi) number of rides in a post-Uber period to the number of taxi rides in a pre-Uber period and found that the total number of rides remained quite stable in post-Uber years. We then tested whether it was relatively easier to get a ride in rainy than in non-rainy hours in 2014-2016. Our results indicated that the total number of rides significantly increased in rainy hours in comparison to non-rainy hours.

The results have important implications for the ongoing debate on whether Uber is depressing taxi demand and whether Uber increases con- 
sumers' welfare. In particular, they highlight that Uber is substituting for taxi cabs in NYC and that surge pricing seems effective in increasing labor supply. Future research could study in more details whether Uber driver labor supply is best characterized by standard neoclassical intertemporal models of labor supply or models of reference-dependent preferences using hourly data on occupancy and number of hacks. 


\section{References}

Agarwal, S., Diao, M., Pan, J. and Sing, T. F.: 2015, Are Singaporean Cabdrivers Target Earners? Mimeo: University of Singapore.

Ashenfelter, O., Doran, K. and Schaller, B.: 2010, A Shred of Credible Evidence on the Long-run Elasticity of Labour Supply, Economica $77(308)$, 637-650.

Blundell, R. and MaCurdy, T.: 1999, Labor Supply: A Review of Alternative Approaches, in O. Ashenfelter and D. Card (eds), Handbook of Labor Economics, Vol. 3A, Amsterdam: North-Holland, pp. 1559-1695.

Buchholz, N.: 2016, Spatial Equilibrium, Search Frictions and Efficient Regulation in the Taxi Industry. Mimeo: University of Texas at Austin.

Camerer, C., Babcock, L., Loewenstein, G. and Thaler, R.: 1997, Labor Supply of New York City Cabdrivers: One Day at a Time, Quarterly Journal of Economics 112(2), 407-441.

Chang, T. and Gross, T.: 2014, How Many Pears Would a Pear Packer Pack if a Pear Packer Could Pack Pears at Quasi-Exogenously Varying Piece Rates?, Journal of Economic Behavior \& Organization 99(C), 1-17.

Chen, M. K., Chevalier, J. A., Rossi, P. E. and Oehlsen, E.: 2017, The Value of Flexible Work: Evidence from Uber Drivers. NBER Working Papers 23296.

Chen, M. K. and Sheldon, M.: 2015, Dynamic Pricing in a Labor Market: Surge Pricing and Flexible Work on the Uber Platform. Mimeo: UCLA Anderson School of Management.

Chou, Y. K.: 2002, Testing Alternative Models of Labour Supply: Evidence from Taxi Drivers in Singapore, Singapore Economic Review 47(01), 1747.

Cohen, P., Hahn, R., Hall, J., Levitt, S. and Metcalfe, R.: 2016, Using Big Data to Estimate Consumer Surplus: The Case of Uber. NBER Working Papers 22627.

Connolly, M.: 2008, Here Comes the Rain Again: Weather and the Intertemporal Substitution of Leisure, Journal of Labor Economics 26(1), 73-100. 
Cramer, J. and Krueger, A. B.: 2016, Disruptive Change in the Taxi Business: The Case of Uber, American Economic Review, Papers and Proceedings 106(5), 177-182.

Crawford, V. P. and Meng, J.: 2011, New York City Cab Drivers' Labor Supply Revisited: Reference-Dependent Preferences with Rational Expectations Targets for Hours and Income, American Economic Review 101(5), 1912-1932.

Doran, K.: 2014, Are Long-Term Wage Elasticities of Labor Supply More Negative than Short-Term Ones?, Economics Letters 122(2), 208-210.

Farber, H. S.: 2005, Is Tomorrow Another Day? The Labor Supply of New York City Cabdrivers, Journal of Political Economy 113(1), 46-82.

Farber, H. S.: 2008, Reference-Dependent Preferences and Labor Supply: The Case of New York City Taxi Drivers, American Economic Review 98(3), 1069-1082.

Farber, H. S.: 2015, Why you Can't Find a Taxi in the Rain and Other Labor Supply Lessons from Cab Drivers, Quarterly Journal of Economics 130(4), 1975-2026.

Fehr, E. and Goette, L.: 2007, Do Workers Work More if Wages Are High? Evidence from a Randomized Field Experiment, American Economic Review 97(1), 298-317.

Haggag, K., McManus, B. and Paci, G.: 2017, Learning by Driving: Productivity Improvements by New York City Taxi Drivers, American Economic Journal: Applied Economics 9(1), 70-95.

Haggag, K. and Paci, G.: 2014, Default Tips, American Economic Journal: Applied Economics 6(3), 1-19.

Hall, J. V. and Krueger, A. B.: 2016, An Analysis of the Labor Market for Uber's Driver-Partners in the United States. NBER Working Papers 22843.

Kahneman, D. and Tversky, A.: 1979, Prospect Theory: An Analysis of Decision under Risk, Econometrica 47(2), 263-292.

Koszegi, B. and Rabin, M.: 2006, A Model of Reference-Dependent Preferences, Quarterly Journal of Economics 121(4), 1133-1165. 
Oettinger, G.: 1999, An Empirical Analysis of the Daily Labor Supply of Stadium Vendors, Journal of Political Economy 107(2), 360-392.

Tversky, A. and Kahneman, D.: 1991, Loss Aversion in Riskless Choice: A Reference-Dependent Model, Quarterly Journal of Economics 106(4), 1039-1061. 


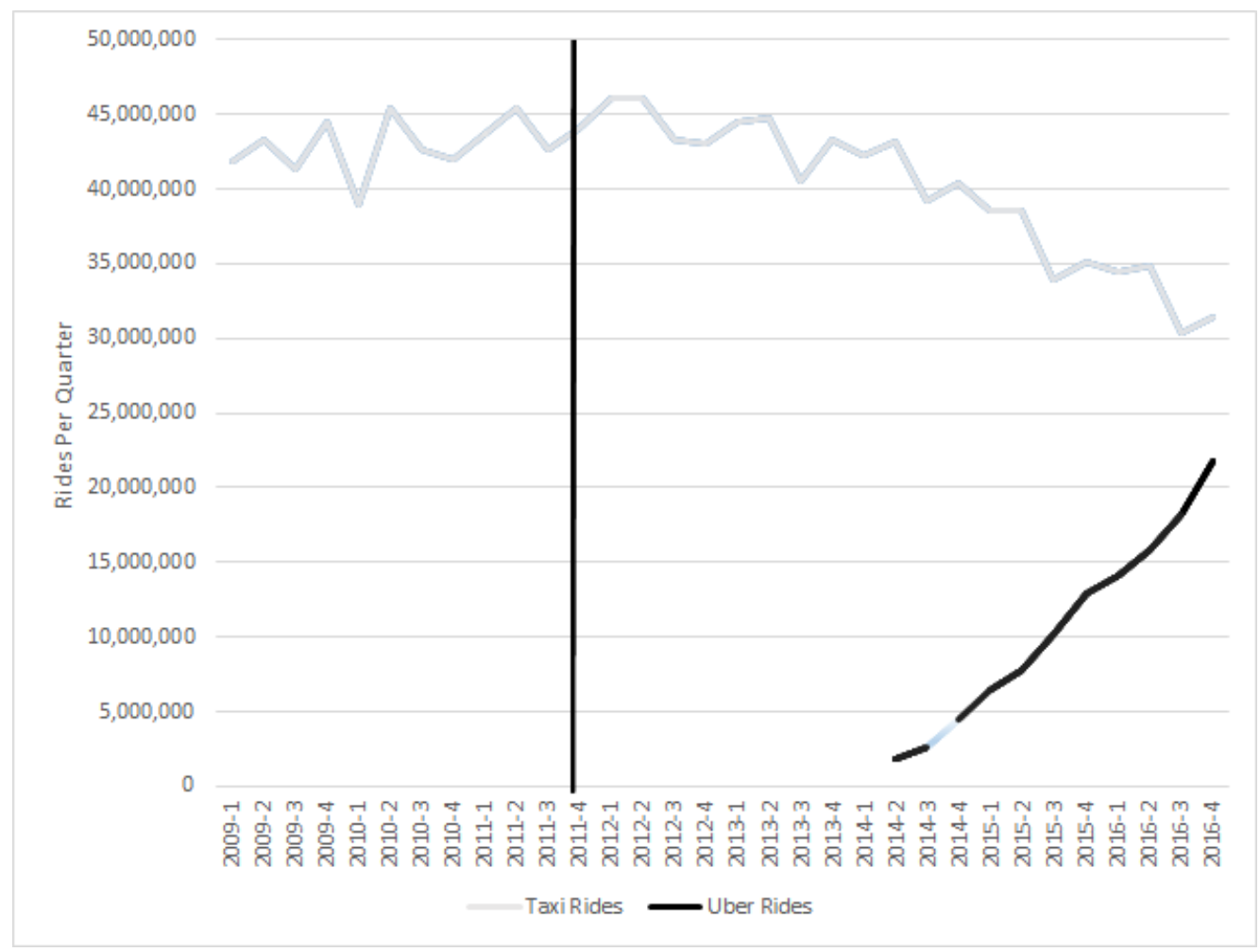

Figure 1: Number of Uber and taxi rides per quarter. Uber entered the market in May 2011. 


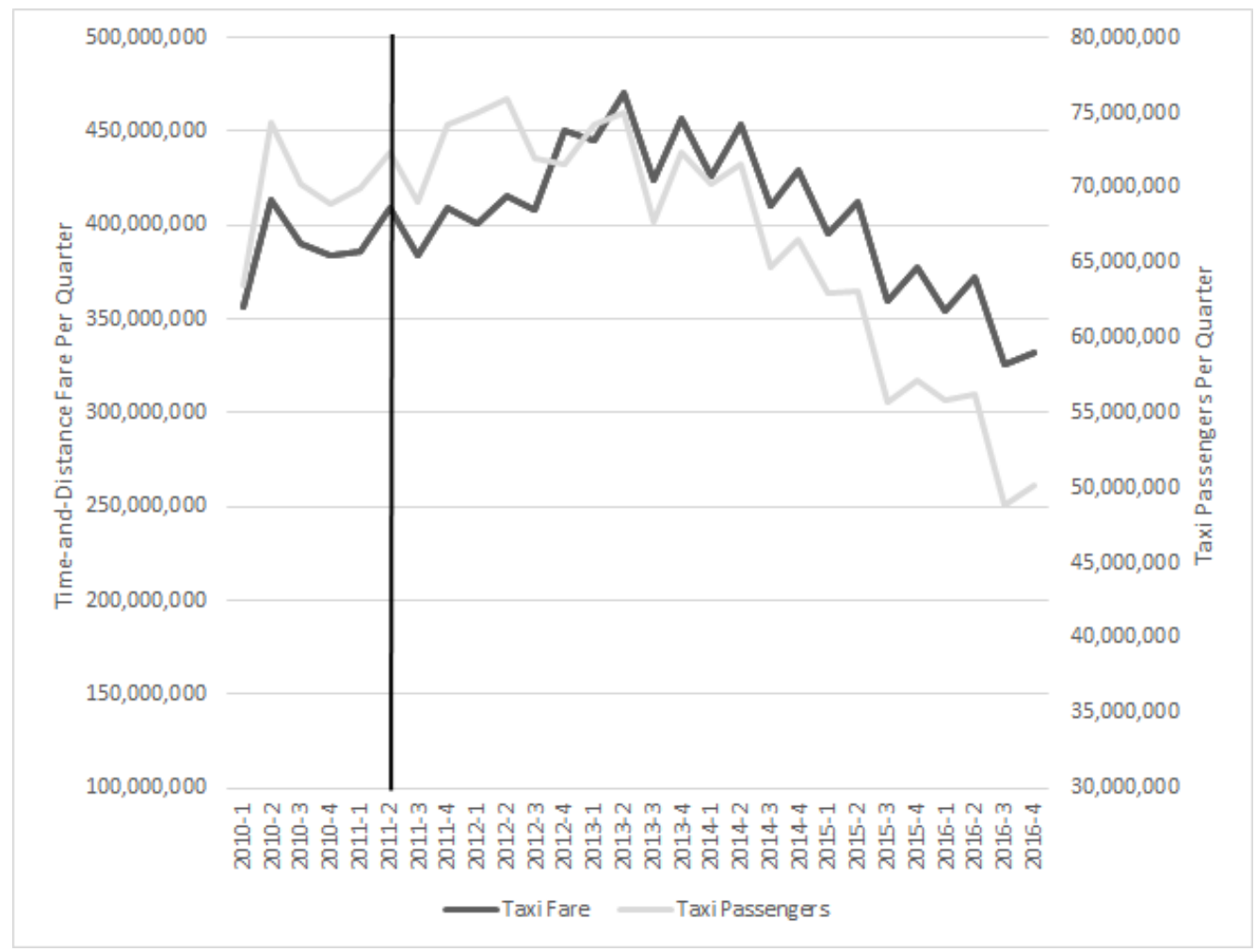

Figure 2: Number of number of taxi passengers and total time-and-distance fare (in 2010 dollars) as calculated by the taxi meter per quarter. Uber entered the market in May 2011. 


\section{Tables}

Table 1: Summary Statistics (per Hour).

\begin{tabular}{|c|c|c|c|c|c|}
\hline & Mean & Std. Dev. & Max & Min & Obs. \\
\hline \multicolumn{6}{|l|}{ Panel A } \\
\hline Uber Rides & 5,076 & 4,052 & 28,133 & 18 & 21,423 \\
\hline Taxi Rides (Post-Uber) & 16,439 & 7,447 & 36,655 & 257 & 21,423 \\
\hline Taxi Rides (Pre-Uber) & 19,519 & 9,331 & 53,022 & 209 & 11,551 \\
\hline
\end{tabular}

Panel B

Dropped Night (1:00 - 5:00 AM)

\begin{tabular}{|c|c|c|c|c|c|}
\hline Uber Rides & 5,854 & 4,066 & 28,133 & 18 & 16,973 \\
\hline Taxi Rides (Post-Uber) & 19,097 & 5,445 & 34,983 & 257 & 16,973 \\
\hline Taxi Rides (Pre-Uber) & 23,065 & 7,042 & 53,022 & 426 & 7,437 \\
\hline
\end{tabular}

Panel C

Dropped Winter (January - March)

$\begin{array}{lccccc}\text { Uber Rides } & 5,156 & 4,242 & 28,133 & 43 & 17,125 \\ \text { Taxi Rides (Post-Uber) } & 16,316 & 7,341 & 36,655 & 1,371 & 17,125 \\ \text { Taxi Rides (Pre-Uber) } & 19,764 & 9,010 & 53,022 & 209 & 7,264\end{array}$

Note: Authors' calculations. We report rides per hour. See Data section for more details. The time period pre-Uber is January 2010-April 2011. The period post-Uber is April-September 2014 and 2015-2016. Panel B excludes from the sample rides from 1:00 to 5:00 AM. Panel C excludes from the sample the months of January, February and March. 
Table 2: Weather Data

\begin{tabular}{|c|c|c|}
\hline & Post-Uber Period & Pre-Uber Period \\
\hline Heavy Rain & $56(0.3 \%)$ & $31(0.3 \%)$ \\
\hline Rain & $155(0.7 \%)$ & $111(0.9 \%)$ \\
\hline Light Rain & $711(3.3 \%)$ & $385(3.3 \%)$ \\
\hline Light Freezing Rain & $11(0.1 \%)$ & $14(0.2 \%)$ \\
\hline Heavy Snow & $8(0.0 \%)$ & $18(0.2 \%)$ \\
\hline Snow & $53(0.3 \%)$ & $55(0.5 \%)$ \\
\hline Light Snow & $120(0.6 \%)$ & $130(1.1 \%)$ \\
\hline Clear & $11,496(53.7 \%)$ & $6,166(53.4 \%)$ \\
\hline Scattered Clouds & $901(4.2 \%)$ & $438(3.8 \%)$ \\
\hline Partly Cloudy & $1,244(5.8 \%)$ & $616(5.3 \%)$ \\
\hline Mostly Cloudy & $1,656(7.7 \%)$ & $805(7.0 \%)$ \\
\hline Overcast & $4,509(21.1 \%)$ & $2,611(22.6 \%)$ \\
\hline Fog & $5(0.0 \%)$ & $4(0.1 \%)$ \\
\hline Haze & $495(2.3 \%)$ & $167(1.5 \%)$ \\
\hline Mist & $2(0.0 \%)$ & $0(0.0 \%)$ \\
\hline Total & $21,422(100 \%)$ & $11,551(100 \%)$ \\
\hline
\end{tabular}


Table 3: Effect of Rain on Taxi and Uber Rides per Hour: Post-Uber.

\begin{tabular}{|c|c|c|c|c|c|c|}
\hline Natural log of & $\begin{array}{c}\text { Taxi Rides } \\
\text { (1) }\end{array}$ & $\begin{array}{c}\text { Taxi Rides } \\
\text { (2) }\end{array}$ & $\begin{array}{c}\text { Taxi Rides } \\
\text { Exclude } \\
\text { Night } \\
(3)\end{array}$ & $\begin{array}{l}\text { Uber Rides } \\
\qquad(4)\end{array}$ & $\begin{array}{l}\text { Uber Rides } \\
\qquad(5)\end{array}$ & $\begin{array}{c}\text { Uber Rides } \\
\text { Exclude } \\
\text { Night } \\
(6)\end{array}$ \\
\hline Rain & $\begin{array}{c}0.014 \\
(0.026)\end{array}$ & $\begin{array}{c}0.046 \\
(0.004)\end{array}$ & $\begin{array}{c}0.046 \\
(0.005)\end{array}$ & $\begin{array}{c}0.142 \\
(0.036)\end{array}$ & $\begin{array}{c}0.189 \\
(0.011)\end{array}$ & $\begin{array}{c}0.212 \\
(0.010)\end{array}$ \\
\hline \multicolumn{7}{|l|}{ Control Variables } \\
\hline Hour × Day FE & & $\checkmark$ & $\checkmark$ & & $\checkmark$ & $\checkmark$ \\
\hline Week FE & & $\checkmark$ & $\checkmark$ & & $\checkmark$ & $\checkmark$ \\
\hline Month \& Year FE & & $\checkmark$ & $\checkmark$ & & $\checkmark$ & $\checkmark$ \\
\hline Holiday \& Snow FE & & $\checkmark$ & $\checkmark$ & & $\checkmark$ & $\checkmark$ \\
\hline Observations & 21,423 & 21,423 & 16,973 & 21,423 & 21,423 & 16,973 \\
\hline R-Squared & 0.000 & 0.953 & 0.863 & 0.000 & 0.948 & 0.943 \\
\hline
\end{tabular}

Table 4: Robustness Checks for the Period Post-Uber (per Hour).

\begin{tabular}{|c|c|c|c|c|c|c|}
\hline Natural log of & $\begin{array}{c}\text { Taxi Rides } \\
\text { Exclude } \\
\text { Heavy Rain } \\
\text { (1) }\end{array}$ & $\begin{array}{c}\text { Taxi Rides } \\
\text { Exclude } \\
\text { Winter } \\
(2)\end{array}$ & $\begin{array}{c}\text { Taxi Rides } \\
(3) \\
\end{array}$ & $\begin{array}{c}\text { Uber Rides } \\
\text { Exclude } \\
\text { Heavy Rain } \\
(4) \\
\end{array}$ & $\begin{array}{c}\text { Uber Rides } \\
\text { Exclude } \\
\text { Winter } \\
(5)\end{array}$ & $\begin{array}{c}\text { Uber Rides } \\
(6) \\
\end{array}$ \\
\hline Rain & $\begin{array}{c}0.046 \\
(0.004)\end{array}$ & $\begin{array}{c}0.050 \\
(0.004)\end{array}$ & & $\begin{array}{c}0.180 \\
(0.011)\end{array}$ & $\begin{array}{c}0.198 \\
(0.012)\end{array}$ & \\
\hline Light Rain & & & $\begin{array}{c}0.038 \\
(0.004)\end{array}$ & & & $\begin{array}{c}0.157 \\
(0.011)\end{array}$ \\
\hline Rain \& Heavy Rain & & & $\begin{array}{c}0.077 \\
(0.011)\end{array}$ & & & $\begin{array}{c}0.299 \\
(0.022)\end{array}$ \\
\hline \multicolumn{7}{|l|}{ Control Variables } \\
\hline Hour $\times$ Day FE & $\checkmark$ & $\checkmark$ & $\checkmark$ & $\checkmark$ & $\checkmark$ & $\checkmark$ \\
\hline Week FE & $\checkmark$ & $\checkmark$ & $\checkmark$ & $\checkmark$ & $\checkmark$ & $\checkmark$ \\
\hline Month \& Year FE & $\checkmark$ & $\checkmark$ & $\checkmark$ & $\checkmark$ & $\checkmark$ & $\checkmark$ \\
\hline Holiday \& Snow FE & $\checkmark$ & $\checkmark$ & $\checkmark$ & $\checkmark$ & $\checkmark$ & $\checkmark$ \\
\hline Observations & 21,356 & 17,125 & 21,423 & 21,356 & 17,125 & 21,423 \\
\hline R-Squared & 0.953 & 0.966 & 0.953 & 0.948 & 0.954 & 0.948 \\
\hline $\begin{array}{l}\text { Note: The unit of observ } \\
\text { rides (col. 1-3) and the } \\
\text { conditions were noted as } \\
\text { a dummy that is equal to } \\
\text { dummy that is equal to } \\
4 \text { exclude hours of "Heav } \\
\text { January, February and M }\end{array}$ & $\begin{array}{l}\text { ation is an hour. } \\
\text { tatural log of the } \\
\text { "Heavy Rain", "I } \\
\text { one if the cond } \\
\text { one if the conditi } \\
\text { y Rain" and "Li } \\
\text { arch. The time p }\end{array}$ & $\begin{array}{l}\text { The dependen } \\
\text { number of Uk } \\
\text { Rain", "Light F } \\
\text { ition was note }\end{array}$ & $\begin{array}{l}\text { variables are 1 } \\
\text { rides (col. 4 } \\
\text { ezing Rain" ol } \\
\text { as "Light Rail } \\
\text { as "Heavy Rai } \\
\text { n". Columns } \\
\text { ptember 2014 }\end{array}$ & $\begin{array}{l}\text { Ppectively the } \\
\text { Rain is a du } \\
\text { Light Rain" an } \\
\text { and zero othe } \\
\text { or "Rain" and } \\
\text { and 5 exclude } \\
\text { d 2015-2016. S }\end{array}$ & $\begin{array}{l}\text { ural log of the r } \\
\text { my that is equa } \\
\text { zero otherwise. } \\
\text { ise. Rain \& He } \\
\text { ro otherwise. C } \\
\text { om the sample } \\
\text { ndard errors clu }\end{array}$ & $\begin{array}{l}\text { umber of taxi } \\
1 \text { to one if the } \\
\text { Light Rain is } \\
\text { avy Rain is a } \\
\text { olumns } 1 \text { and } \\
\text { the months of } \\
\text { tered by hour }\end{array}$ \\
\hline
\end{tabular}


Table 5: Effect of Rain on Taxi and Uber Rides per Day: Post-Uber.

\begin{tabular}{|c|c|c|c|c|c|c|}
\hline Natural log of & $\begin{array}{c}\text { Taxi Rides } \\
(1)\end{array}$ & $\begin{array}{c}\text { Taxi Rides } \\
(2)\end{array}$ & $\begin{array}{c}\text { Taxi Rides } \\
(3)\end{array}$ & $\begin{array}{c}\text { Uber Rides } \\
(4)\end{array}$ & $\begin{array}{c}\text { Uber Rides } \\
(5)\end{array}$ & $\begin{array}{c}\text { Uber Rides } \\
(6)\end{array}$ \\
\hline Rain Day & $\begin{array}{c}0.0227 \\
(0.0151)\end{array}$ & $\begin{array}{c}0.0246 \\
(0.0130)\end{array}$ & & $\begin{array}{c}0.0201 \\
(0.0767)\end{array}$ & $\begin{array}{c}0.0781 \\
(0.0310)\end{array}$ & \\
\hline Hours of Rain & & & $\begin{array}{c}0.0033 \\
(0.0019)\end{array}$ & & & $\begin{array}{c}0.0195 \\
(0.0034)\end{array}$ \\
\hline \multicolumn{7}{|l|}{ Control Variables } \\
\hline Week FE & & $\checkmark$ & $\checkmark$ & & $\checkmark$ & $\checkmark$ \\
\hline Month \& Year FE & & $\checkmark$ & $\checkmark$ & & $\checkmark$ & $\checkmark$ \\
\hline Holiday \& Snow FE & & $\checkmark$ & $\checkmark$ & & $\checkmark$ & $\checkmark$ \\
\hline Observations & 789 & 789 & 789 & 789 & 789 & 789 \\
\hline R-Squared & 0.002 & 0.351 & 0.350 & 0.000 & 0.876 & 0.878 \\
\hline $\begin{array}{l}\text { Note: The unit of observ } \\
\text { rides (col. 1-3) and the } \\
\text { and 2015-2016. Rain Da } \\
\text { Freezing Rain" or "Light } \\
\text { to the number of hours in } \\
\text { Robust standard errors a }\end{array}$ & $\begin{array}{l}\text { ation is a day. } \\
\text { hatural log of t } \\
\text { is a dummy t } \\
\text { Rain" at any po } \\
\text { which the cond } \\
\text { e in parenthese }\end{array}$ & $\begin{array}{l}\text { The dependent } \\
\text { he number of } \\
\text { lat is equal to } \\
\text { nt during the d } \\
\text { tions were note }\end{array}$ & $\begin{array}{l}\text { variables are } \mathrm{r} \\
\text { ber rides (col. } \\
\text { ne if the condi } \\
\text { y and zero oth } \\
\text { l as "Heavy Rai }\end{array}$ & $\begin{array}{l}\text { spectively the } n \\
\text { 4-6). The time } \\
\text { ions were noted } \\
\text { rwise. Hours o } \\
\text { ", "Rain", "Ligh }\end{array}$ & $\begin{array}{l}\text { tural log of the } \\
\text { period is April- } \\
\text { as "Heavy Rain" } \\
\text { Rain is a varia } \\
\text { Freezing Rain" }\end{array}$ & $\begin{array}{l}\text { number of tax } \\
\text { September } 201 \\
\text { "Rain", "Ligh } \\
\text { le that is equa } \\
\text { or "Light Rain" }\end{array}$ \\
\hline
\end{tabular}


Table 6: Effect of Rain on Taxi Rides per Hour: Pre- and Post-Uber.

\begin{tabular}{|c|c|c|c|c|c|}
\hline Natural log of & $\begin{array}{c}\text { Taxi Rides } \\
(1)\end{array}$ & $\begin{array}{c}\text { Taxi Rides } \\
(2)\end{array}$ & $\begin{array}{c}\text { Taxi Rides } \\
(3)\end{array}$ & $\begin{array}{c}\text { Taxi Rides } \\
(4)\end{array}$ & $\begin{array}{c}\text { Taxi Rides } \\
(5)\end{array}$ \\
\hline Post-Uber & $\begin{array}{l}-0.269 \\
(0.018)\end{array}$ & $\begin{array}{l}-0.268 \\
(0.018)\end{array}$ & $\begin{array}{l}-0.269 \\
(0.018)\end{array}$ & $\begin{array}{l}-0.436 \\
(0.018)\end{array}$ & $\begin{array}{l}-0.270 \\
(0.018)\end{array}$ \\
\hline Rain & & $\begin{array}{c}0.048 \\
(0.004)\end{array}$ & $\begin{array}{c}0.039 \\
(0.009)\end{array}$ & $\begin{array}{c}0.048 \\
(0.009)\end{array}$ & \\
\hline Rain $\times$ Post-Uber & & & $\begin{array}{c}0.014 \\
(0.010)\end{array}$ & $\begin{array}{c}0.005 \\
(0.010)\end{array}$ & \\
\hline Light Rain & & & & & $\begin{array}{c}0.031 \\
(0.010)\end{array}$ \\
\hline $\begin{array}{l}\text { Light Rain } \\
\times \text { Post-Uber }\end{array}$ & & & & & $\begin{array}{c}0.015 \\
(0.011)\end{array}$ \\
\hline Rain \& Heavy Rain & & & & & $\begin{array}{c}0.062 \\
(0.013)\end{array}$ \\
\hline $\begin{array}{l}\text { Rain \& Heavy Rain } \\
\times \text { Post-Uber }\end{array}$ & & & & & $\begin{array}{c}0.019 \\
(0.018)\end{array}$ \\
\hline \multicolumn{6}{|l|}{ Control Variables } \\
\hline Hour × Day FE & $\checkmark$ & $\checkmark$ & $\checkmark$ & $\checkmark$ & $\checkmark$ \\
\hline $\begin{array}{l}\text { Week \& Month FE } \\
\text { Month × Post-Uber }\end{array}$ & $\checkmark$ & $\checkmark$ & $\checkmark$ & $\begin{array}{l}\checkmark \\
\checkmark\end{array}$ & $\checkmark$ \\
\hline Holiday \& Snow FE & $\checkmark$ & $\checkmark$ & $\checkmark$ & $\checkmark$ & $\checkmark$ \\
\hline Population \& UE Rate & $\checkmark$ & $\checkmark$ & $\checkmark$ & $\checkmark$ & $\checkmark$ \\
\hline Observations & 32,974 & 32,974 & 32,974 & 32,974 & 32,974 \\
\hline R-Squared & 0.926 & 0.926 & 0.926 & 0.928 & 0.926 \\
\hline
\end{tabular}


Table 7: Effect of Rain on Taxi Passengers and Fare per Hour: Pre- and Post-Uber.

\begin{tabular}{|c|c|c|c|c|}
\hline & (1) & (2) & (3) & (4) \\
\hline$\overline{\text { Panel } A}$ & \multicolumn{4}{|c|}{ Natural log of Taxi Passengers } \\
\hline Post-Uber & $\begin{array}{l}-0.185 \\
(0.019)\end{array}$ & $\begin{array}{c}-0.184 \\
(0.019)\end{array}$ & $\begin{array}{l}-0.185 \\
(0.019)\end{array}$ & $\begin{array}{c}-0.410 \\
(0.019)\end{array}$ \\
\hline Rain & & $\begin{array}{c}0.054 \\
(0.005)\end{array}$ & $\begin{array}{c}0.046 \\
(0.010)\end{array}$ & $\begin{array}{c}0.058 \\
(0.010)\end{array}$ \\
\hline Rain $\times$ Post-Uber & & & $\begin{array}{c}0.013 \\
(0.011)\end{array}$ & $\begin{array}{c}0.008 \\
(0.011)\end{array}$ \\
\hline $\begin{array}{l}\text { R-squared } \\
\text { Observations }\end{array}$ & 0.921 & 0.921 & 0.921 & 0.924 \\
\hline
\end{tabular}

Panel B

Natural log of Time-and-Distance Fare

Post-Uber

\begin{tabular}{lccc}
\multicolumn{4}{c}{ Natural log of Time-and-Distance Fare } \\
\hline-0.069 & -0.068 & -0.071 & -0.258 \\
$(0.018)$ & $(0.018)$ & $(0.018)$ & $(0.019)$ \\
& & & \\
& 0.040 & 0.024 & 0.034 \\
& $(0.004)$ & $(0.008)$ & $(0.009)$ \\
& & 0.025 & 0.014 \\
& & $(0.009)$ & $(0.009)$ \\
& & & 0.920 \\
\hline 0.918 & 0.918 & 0.918 & \\
\hline
\end{tabular}

R-squared

Observations

\begin{tabular}{llll}
$\checkmark$ & $\checkmark$ & $\checkmark$ & $\checkmark$ \\
$\checkmark$ & $\checkmark$ & $\checkmark$ & $\checkmark$ \\
& & & $\checkmark$ \\
$\checkmark$ & $\checkmark$ & $\checkmark$ & $\checkmark$ \\
$\checkmark$ & $\checkmark$ & $\checkmark$ \\
\hline
\end{tabular}

Control Variables

Hour $\times$ Day FE

Week \& Month FE

Month $\times$ Post-Uber

Holiday \& Snow FE

Population \& UE Rate

Note: The unit of observation is an hour. The dependent variable in Panel A is the natural log of the number of taxi passengers. The dependent variable in Panel B is the natural log of the total time-and-distance fare as calculated by the taxi meter per hour (in 2010 dollars). The time period is January 2010-April 2011, April-September 2014 and 2015-2016. Rain is a dummy that is equal to one if the conditions were noted as "Heavy Rain", "Rain", "Light Freezing Rain" or "Light Rain" and zero otherwise. Post Uber is a dummy that is equal to one for the period April-September 2014 and 2015-2016 and zero otherwise. Standard errors clustered by hour of day by day of week (168 clusters) are in parentheses. 
Table 8: Effect of Rain on Total (Taxi and Uber) Rides per Hour: Pre- and Post-Uber.

\begin{tabular}{|c|c|c|c|c|c|}
\hline Natural log of & $\begin{array}{c}\text { Total Rides } \\
(1)\end{array}$ & $\begin{array}{c}\text { Total Rides } \\
(2)\end{array}$ & $\begin{array}{c}\text { Total Rides } \\
(3)\end{array}$ & $\begin{array}{c}\text { Total Rides } \\
(4)\end{array}$ & $\begin{array}{c}\text { Total Rides } \\
(5) \\
\end{array}$ \\
\hline Post-Uber & $\begin{array}{l}-0.002 \\
(0.016)\end{array}$ & $\begin{array}{l}-0.000 \\
(0.017)\end{array}$ & $\begin{array}{l}-0.004 \\
(0.016)\end{array}$ & $\begin{array}{l}-0.050 \\
(0.018)\end{array}$ & $\begin{array}{l}-0.005 \\
(0.017)\end{array}$ \\
\hline Rain & & $\begin{array}{c}0.071 \\
(0.005)\end{array}$ & $\begin{array}{l}0.047 \\
(0.010)\end{array}$ & $\begin{array}{l}0.053 \\
(0.009)\end{array}$ & \\
\hline Rain $\times$ Post-Uber & & & $\begin{array}{l}0.038 \\
(0.011)\end{array}$ & $\begin{array}{c}0.031 \\
(0.010)\end{array}$ & \\
\hline Light Rain & & & & & $\begin{array}{l}0.038 \\
(0.011)\end{array}$ \\
\hline $\begin{array}{l}\text { Light Rain } \\
\times \text { Post-Uber }\end{array}$ & & & & & $\begin{array}{l}0.030 \\
(0.012)\end{array}$ \\
\hline Rain \& Heavy Rain & & & & & $\begin{array}{l}0.076 \\
(0.015)\end{array}$ \\
\hline $\begin{array}{l}\text { Rain \& Heavy Rain } \\
\times \text { Post-Uber }\end{array}$ & & & & & $\begin{array}{c}0.065 \\
(0.018)\end{array}$ \\
\hline Control Variables & & & & & \\
\hline Hour $\times$ Day FE & $\checkmark$ & $\checkmark$ & $\checkmark$ & $\checkmark$ & $\checkmark$ \\
\hline $\begin{array}{l}\text { Week \& Month FE } \\
\text { Month } \times \text { Post-Uber }\end{array}$ & $\checkmark$ & $\checkmark$ & $\checkmark$ & $\begin{array}{l}\checkmark \\
\checkmark\end{array}$ & $\checkmark$ \\
\hline Holiday \& Snow FE & $\checkmark$ & $\checkmark$ & $\checkmark$ & $\checkmark$ & $\checkmark$ \\
\hline Population \& UE Rate & $\checkmark$ & $\checkmark$ & $\checkmark$ & $\checkmark$ & $\checkmark$ \\
\hline Observations & 32,974 & 32,974 & 32,974 & 32,974 & 32,974 \\
\hline R-Squared & 0.926 & 0.926 & 0.926 & 0.928 & 0.926 \\
\hline
\end{tabular}

Note: The unit of observation is an hour. The dependent variable is the natural log of the number of total (taxi plus Uber) rides. The time period is January 2010-April 2011, April-September 2014 and 2015-2016. Rain is a dummy that is equal to one if the conditions were noted as "Heavy Rain", "Rain", "Light Freezing Rain" or "Light Rain" and zero otherwise. Light Rain is a dummy that is equal to one if the condition was noted as "Light Rain" and zero otherwise. Rain \& Heavy Rain is a dummy that is equal to one if the conditions were noted as "Heavy Rain" or "Rain" and zero otherwise. Post Uber is a dummy that is equal to one for the period April-September 2014 and 2015-2016 and zero otherwise. Standard errors clustered by hour of day by day of week (168 clusters) are in parentheses. 


\section{Appendix (NOT FOR PUBLICATION)}

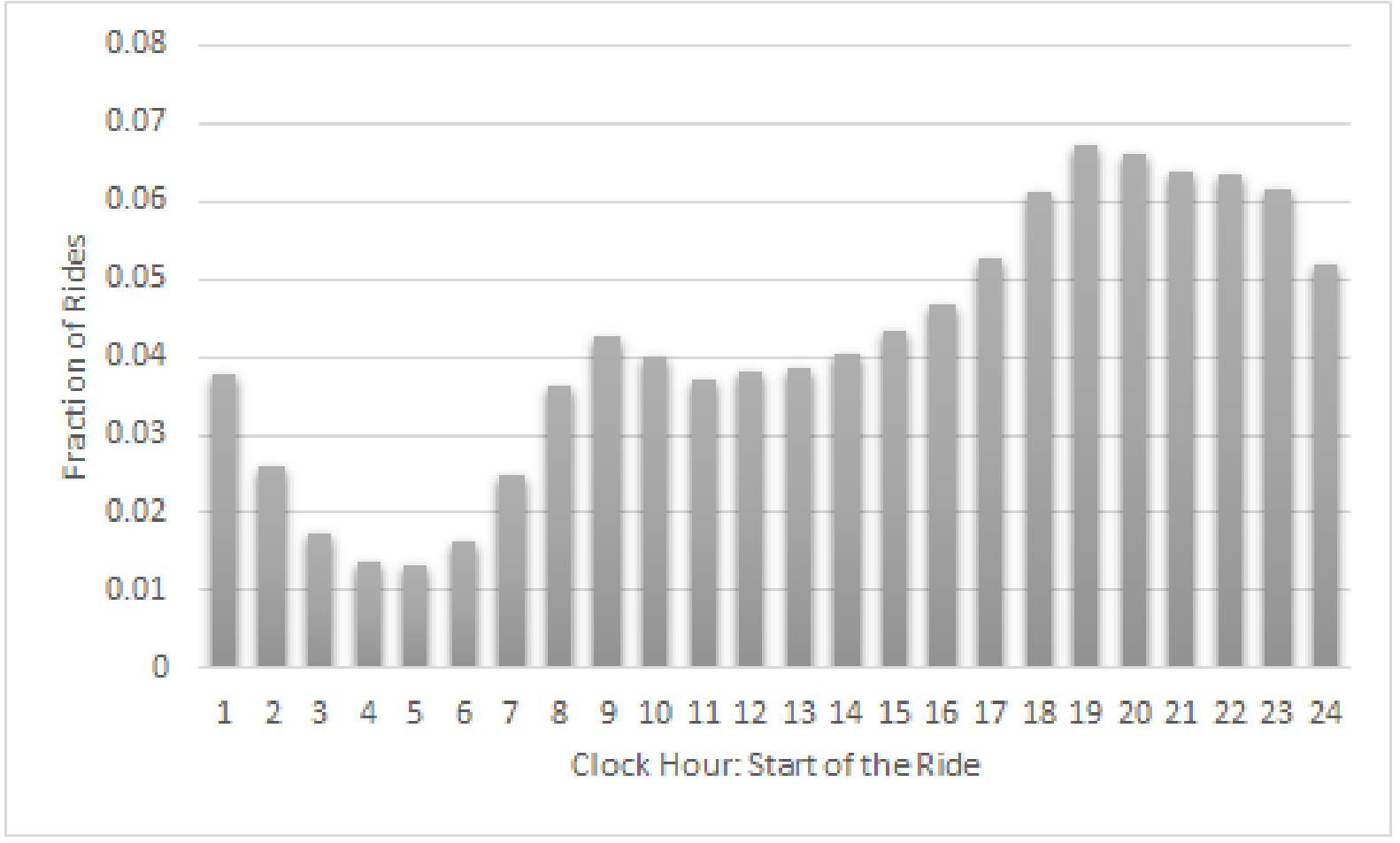

Figure 3: Fraction of Uber rides per hour of day. The time period is April-September 2014 and January 2015 to December 2016.

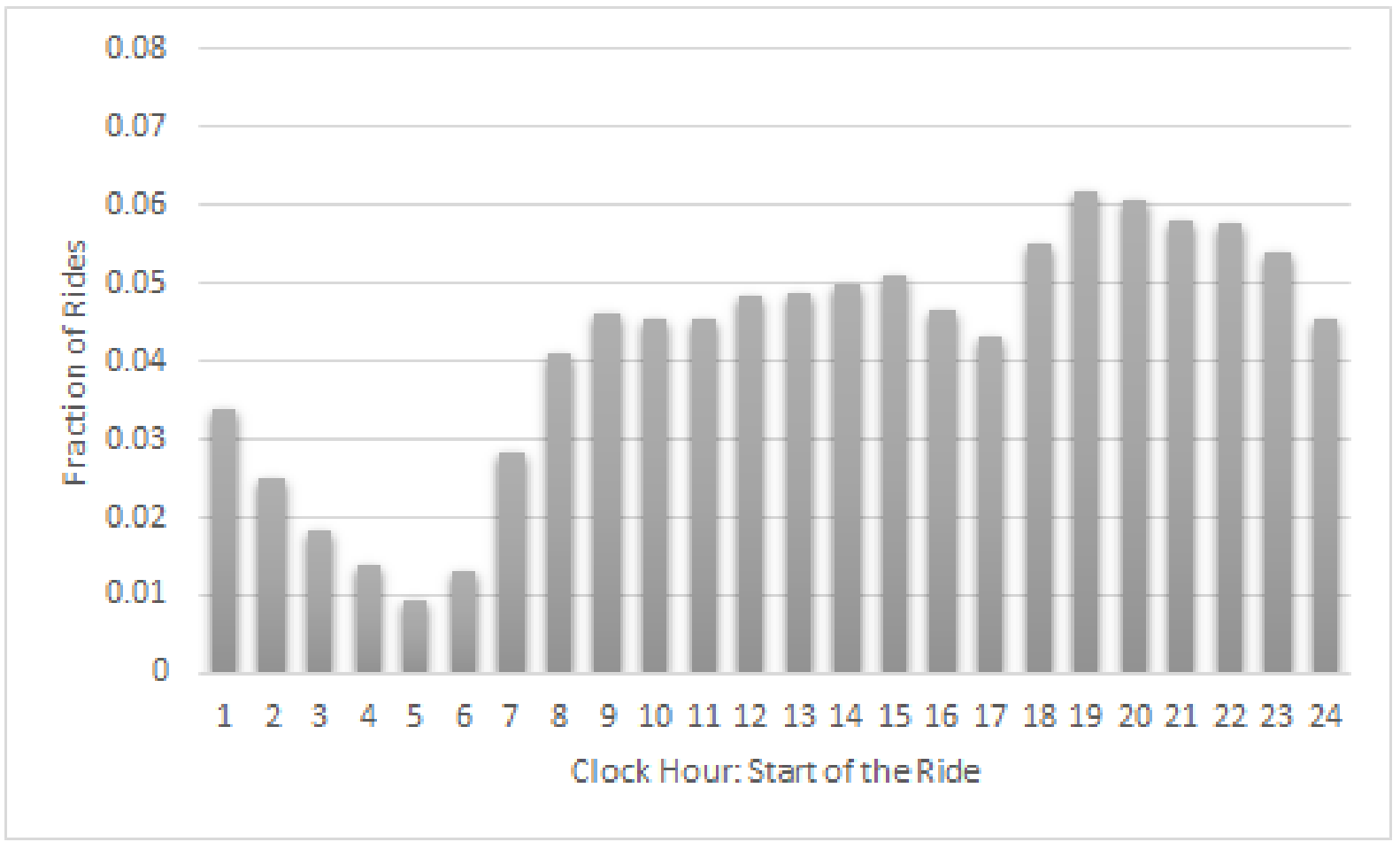

Figure 4: Fraction of taxi rides per hour of day. The time period is April-September 2014 and January 2015 to December 2016 (post-Uber). 
Table A1: Summary Statistics (per Day).

\begin{tabular}{|c|c|c|c|c|c|}
\hline & Mean & Std. Dev. & Max & Min & Obs. \\
\hline \multicolumn{6}{|l|}{ Panel A } \\
\hline Uber Rides & 119,771 & 71,777 & 358,654 & 46 & 908 \\
\hline Taxi Rides (Post-Uber) & 388,768 & 67,213 & 547,097 & 20,921 & 908 \\
\hline Taxi Rides (Pre-Uber) & 464,867 & 88,006 & 835,489 & 73,432 & 485 \\
\hline
\end{tabular}

Panel B

Dropped Winter (January - March)

\begin{tabular}{|c|c|c|c|c|c|}
\hline Uber Rides & 122,314 & 75,831 & 358,654 & 1,680 & 744 \\
\hline Taxi Rides (Post-Uber) & 384,524 & 69,911 & 547,097 & 20,921 & 744 \\
\hline Taxi Rides (Pre-Uber) & 470,699 & 84,026 & 835,489 & 73,432 & 305 \\
\hline
\end{tabular}

Note: Authors' calculations. We report rides per day. See Data section for more details. The time period pre-Uber is January 2010-April 2011. The period post-Uber is April-September 2014 and 2015-2016. Panel B excludes from the sample the months of January, February and March. 
Table A2: Effect of Rain on Taxi Passengers and Fare per Day: Post-Uber.

\begin{tabular}{|c|c|c|c|}
\hline & (1) & (2) & (3) \\
\hline$\overline{\text { Panel } A}$ & \multicolumn{3}{|c|}{ Natural log of Taxi Passengers } \\
\hline Rain Day & $\begin{array}{c}0.0247 \\
(0.0154)\end{array}$ & $\begin{array}{c}0.0256 \\
(0.0133)\end{array}$ & \\
\hline Hours of Rain & & & $\begin{array}{c}0.0032 \\
(0.0020)\end{array}$ \\
\hline $\begin{array}{l}\text { R-squared } \\
\text { Observations }\end{array}$ & 0.002 & $\begin{array}{r}0.365 \\
7\end{array}$ & 0.364 \\
\hline
\end{tabular}

Panel B

Natural log of Time-and-Distance Fare

Rain Day

$0.0197 \quad 0.0211$

$(0.0158) \quad(0.0135)$

Hours of Rain

0.0030

$(0.0019)$

R-squared

Observations

\begin{tabular}{lcc}
0.343 & 0.343 \\
& 789 & \\
\hline
\end{tabular}

\section{Control Variables}

Week FE

Month \& Year FE

Holiday \& Snow FE

$\begin{array}{ll}\checkmark & \checkmark \\ \checkmark & \checkmark \\ \checkmark & \checkmark\end{array}$

Note: The unit of observation is a day. The dependent variable in Panel A is the natural log of the number of taxi passengers. The dependent variable in Panel B the natural log of the total time-and-distance fare (in 2010 dollars) as calculated by the taxi meter per hour. The time period is April-September 2014 and 2015-2016. Rain Day is a dummy that is equal to one if the conditions were noted as "Heavy Rain", "Rain", "Light Freezing Rain" or "Light Rain" at any point during the day and zero otherwise. Hours of Rain is a variable that is equal to the number of hours in which the conditions were noted as "Heavy Rain", "Rain", "Light Freezing Rain" or "Light Rain". Robust standard errors are in parentheses. 
Table A3: Effect of Rain on Taxi Rides per Day: Pre- and Post-Uber.

\begin{tabular}{|c|c|c|c|c|}
\hline Natural log of & $\begin{array}{c}\text { Taxi Rides } \\
\text { (1) }\end{array}$ & $\begin{array}{c}\text { Taxi Rides } \\
(2)\end{array}$ & $\begin{array}{c}\text { Taxi Rides } \\
(3)\end{array}$ & $\begin{array}{c}\text { Taxi Rides } \\
(4)\end{array}$ \\
\hline Post-Uber & $\begin{array}{l}-0.508 \\
(0.150)\end{array}$ & $\begin{array}{l}-0.504 \\
(0.149)\end{array}$ & $\begin{array}{l}-0.518 \\
(0.150)\end{array}$ & $\begin{array}{l}-0.742 \\
(0.174)\end{array}$ \\
\hline Rain Day & & $\begin{array}{c}0.015 \\
(0.011)\end{array}$ & $\begin{array}{l}-0.007 \\
(0.021)\end{array}$ & $\begin{array}{l}-0.007 \\
(0.021)\end{array}$ \\
\hline Rain Day $\times$ Post-Uber & & & $\begin{array}{l}0.035 \\
(0.024)\end{array}$ & $\begin{array}{c}0.037 \\
(0.025)\end{array}$ \\
\hline \multicolumn{5}{|l|}{ Control Variables } \\
\hline $\begin{array}{l}\text { Week \& Month FE } \\
\text { Month } \times \text { Post-Uber }\end{array}$ & $\checkmark$ & $\checkmark$ & $\checkmark$ & $\begin{array}{l}\checkmark \\
\checkmark\end{array}$ \\
\hline Holiday \& Snow FE & $\checkmark$ & $\checkmark$ & $\checkmark$ & $\checkmark$ \\
\hline Population \& UE Rate & $\checkmark$ & $\checkmark$ & $\checkmark$ & $\checkmark$ \\
\hline Observations & 1,274 & 1,211 & 1,211 & 1,211 \\
\hline R-Squared & 0.324 & 0.325 & 0.326 & 0.352 \\
\hline
\end{tabular}

Table A4: Effect of Rain on Total (Taxi and Uber) Rides per Day: Pre- and Post-Uber.

\begin{tabular}{|c|c|c|c|c|}
\hline Natural log of & $\begin{array}{l}\text { Total Rides } \\
\text { (1) }\end{array}$ & $\begin{array}{c}\text { Total Rides } \\
(2)\end{array}$ & $\begin{array}{c}\text { Total Rides } \\
\quad(3)\end{array}$ & $\begin{array}{l}\text { Total Rides } \\
(4)\end{array}$ \\
\hline Post-Uber & $\begin{array}{l}-0.202 \\
(0.147)\end{array}$ & $\begin{array}{l}-0.195 \\
(0.146)\end{array}$ & $\begin{array}{l}-0.216 \\
(0.146)\end{array}$ & $\begin{array}{l}-0.349 \\
(0.169)\end{array}$ \\
\hline Rain Day & & $\begin{array}{c}0.023 \\
(0.012)\end{array}$ & $\begin{array}{l}-0.009 \\
(0.021)\end{array}$ & $\begin{array}{l}-0.010 \\
(0.021)\end{array}$ \\
\hline Rain Day $\times$ Post-Uber & & & $\begin{array}{c}0.052 \\
(0.024)\end{array}$ & $\begin{array}{l}0.054 \\
(0.025)\end{array}$ \\
\hline \multicolumn{5}{|l|}{ Control Variables } \\
\hline $\begin{array}{l}\text { Week \& Month FE } \\
\text { Month } \times \text { Post-Uber }\end{array}$ & $\checkmark$ & $\checkmark$ & $\checkmark$ & $\begin{array}{l}\checkmark \\
\checkmark\end{array}$ \\
\hline Holiday \& Snow FE & $\checkmark$ & $\checkmark$ & $\checkmark$ & $\checkmark$ \\
\hline Population \& UE Rate & $\checkmark$ & $\checkmark$ & $\checkmark$ & $\checkmark$ \\
\hline Observations & 1,274 & 1,274 & 1,274 & 1,274 \\
\hline R-Squared & 0.251 & 0.253 & 0.255 & 0.283 \\
\hline
\end{tabular}

